\title{
FORMALISM VERSUS REALISM: THE INTERNATIONAL COURT OF JUSTICE AND THE CRITICAL DATE FOR ASSESSING JURISDICTION
}

\author{
Daniel West*
}

\begin{abstract}
The 2011 judgment in Georgia v Russian Federation represents an apparent watershed in the approach of the International Court of Justice in ascertaining the critical date for assessing jurisdiction. With few historic exceptions, the Court had previously applied a doctrine of realism that allowed for the resolution of procedural defects between the date of seisin and the Court's decision on jurisdiction. In Georgia however, the Court applied a formalistic approach that assessed competence solely by reference to the date on which the application was filed, and accordingly declined jurisdiction. This vacillating approach to the critical date is an example of how the Court exercises interpretative discretion to further its own procedural objectives through engagement in judicial case selection. This practice will be criticised on two grounds: first for depriving the Court of opportunities to fulfil its primary function of developing international law, and second for betraying an institution that has applied formalism on an ad-hoc basis on political grounds. It will be concluded that the Court's broader institutional function would be better served through the adoption of a blanket and permanent approach of flexible realism in allowing for the post-filing resolution of jurisdictional defects.
\end{abstract}

\section{A. INTRODUCTION}

As with any international judicial institution, the ability of the International Court of Justice (the Court) to fulfil its role is shaped intrinsically by the scope of its jurisdiction. With competence circumscribed by the parameters of state consent, ${ }^{1}$ the Court's exercise of jurisdiction becomes the gatekeeper that dictates the volume and substance of the matters upon which it promulgates. Although jurisdiction at its most basic level retains a fundamentally binary character - it is either present or not - elements of interpretative discretion exist within the Court's exercise of its competence de la competence. ${ }^{2}$ The result, Shany suggests, is that the exercise of jurisdiction serves as an 'effectiveness-influencing variable' that enables the Court to engage in a form of case selection informed by the pursuit of its institutional objectives. $^{3}$

\footnotetext{
* LLM, University College London. I am grateful to Professor Philippe Sands QC for guidance provided during the writing of the dissertation on which this article is based, and to Luis Felipe Viveros for his helpful comments.

${ }^{1}$ The jurisdiction of the Court in contentious cases is defined by its deference to the consent of the parties. The Court can therefore 'only exercise jurisdiction over a State with its consent'; Case of the Monetary Gold Removed from Rome in 1943 (Preliminary Question), Judgment of June 15th, 1954: ICJ Reports 1954, 19, 32.

${ }^{2}$ Provided for by article 36(6) of the Statute of the International Court of Justice (the Statute); annexed to the Charter of the United Nations (adopted 26 June 1945, entered into force 24 October 1945) 1 UNTS XVI 46 (the UN Charter).

${ }^{3}$ Yuval Shany, Assessing the Effectiveness of International Courts (OUP 2014) 87-88.
} 


\section{Formalism Versus Realism: The International Court of Justice and the Critical Date for Assessing Jurisdiction}

One area of jurisdictional discretion in which the Court has recently exhibited a growing tendency to deprive itself of competence is its approach to ascertaining the critical date for jurisdiction. In particular, the 2011 judgment of the Court in the case of Georgia v Russian Federation arguably departed from a century of previous jurisprudence, applying a formalist approach that assessed jurisdiction solely by reference to the date of seisin. ${ }^{4}$ By declining to consider the potential resolution of procedural defects after this date, the Court seemingly telegraphed a shift away from the realism evident in decisions as recent as Croatia $v$ Serbia. ${ }^{5}$ A review of the Court's current docket of pending cases demonstrates the current significance of this issue, with Colombia having invoked the Court's recent tendency towards formalism to argue that it lacks jurisdiction to adjudicate one of its ongoing disputes with Nicaragua. ${ }^{6}$ For academic observers of the Court, this vacillating approach to assessing the critical date for jurisdiction is a prime example of how the Court's exercise of discretion can influence its jurisdictional reach. It is accordingly both a key indicator of the Court's perception of its own institutional purpose and its effectiveness in performing this role. It is through the prism of this narrow temporal issue of jurisdiction that this paper shall thus seek to expound a more comprehensive macro-analysis of the Court's current geopolitical function.

It will be argued that the Court's recent adherence to the formalist approach when assessing the critical date for jurisdiction is unfortunate in two key respects: first in depriving the Court of opportunities to fulfil what should be its primary function of developing international law, and second in betraying an institution that has applied formalism on an ad hoc basis to engage in case-selection on political grounds. Section B will begin by introducing the normative dichotomy between formalism and realism within the context of the critical date. ${ }^{7}$ Section $\mathrm{C}$ will examine the relevant jurisprudence of the Court, discerning a recent trend away from realism and towards formalism. This will lay the foundations for Section D, an

\footnotetext{
${ }^{4}$ Application of the International Convention on the Elimination of All Forms of Racial Discrimination (Georgia $v$ Russian Federation), Preliminary Objections, Judgment, ICJ Reports 2011, 70 (Georgia).

${ }^{5}$ Application of the Convention on the Prevention and Punishment of the Crime of Genocide (Croatia v Serbia), Preliminary Objections, Judgment, ICJ Reports 2008, 412 (Croatian Genocide).

${ }^{6}$ Preliminary Objections of the Republic of Colombia in Alleged Violations of Sovereign Rights and Maritime Spaces in the Caribbean Sea (Nicaragua v Colombia), 19 December 2014 (Colombia PO), Chapter 4.

${ }^{7}$ The terms 'formalism' and 'realism' have historically been ascribed a number of different meanings within the sphere of international legal theory (see for example Jean d'Aspremont, Formalism and the Sources of International Law: A Theory of the Ascertainment of Legal Rules (OUP 2011) and Daniel Bodansky, 'Legal Realism and its Discontents' (2015) 28 Leiden Journal of International Law 267). For the somewhat narrower purpose of this article, the term formalism is used to refer to the strict adherence to fixed procedural rules regardless of the congruity of practical consequence. Conversely, realism advocates a more flexible approach that takes into account all prevailing circumstances to reach a pragmatic conclusion that is more consistent with the Court's institutional objectives. More detail on the practical differences between the two approaches as derived from the relevant case law is set out in Section B below.
} 
appraisal of the Court's current position on the critical date through an analysis of the circumstances that triggered the apparent change of approach in Georgia, and how the reasoning in that case has been applied in subsequent judgments. Finally, Section E will consider the Court's approach to temporal matters of jurisdiction within the wider context of its overall effectiveness, arguing for a more flexible approach to jurisdiction informed by realism and concluding with some suggestions for the future.

\section{B. FORMALISM, REALISM AND THE CRITICAL DATE}

In the Arrest Warrant case, the Court noted that its settled jurisprudence required jurisdiction to be 'determined at the time that the act instituting proceedings was filed'. ${ }^{8}$ Judicial statements such as this are indicative of a jurisprudence constante, reflecting a number of previous judgments that have expressed the same view. ${ }^{9}$ However, the Court has in certain circumstances been willing to apply a more realistic approach to ascertaining the critical date. The result is that it has not always proved necessary for jurisdictional preconditions to have crystallised at the date of filing. ${ }^{10}$

This qualification to the jurisprudence constante has its roots in judgments dating back to the Permanent Court of International Justice (PCIJ) and its decision in the Mavromattis case. ${ }^{11}$ In that case, Greece as the applicant sought to establish jurisdiction against the United Kingdom pursuant to the Treaty of Lausanne, a convention that had not been ratified at the date of application but had entered into force by the time the PCIJ came to decide on jurisdiction. ${ }^{12}$ In a celebrated judgment, the PCIJ held that a jurisdictional defect cured between the application and the date on which jurisdiction is assessed should not preclude the Court from hearing the merits:

The Court, whose jurisdiction is international, is not bound to attach to matters of form the same degree of importance which they might possess in municipal law. Even, therefore, if the application were premature because the Treaty of Lausanne had not yet

\footnotetext{
${ }^{8}$ Arrest Warrant of 11 April 2000 (Democratic Republic of Congo v Belgium), Judgment, ICJ Reports 2002, 3, [26].

${ }^{9}$ Christoph Schreuer, 'At what time must jurisdiction exist?' in David D Caron and others (eds), Practising Virtue Inside International Arbitration (OUP 2016) 266-267.

${ }^{10}$ Hugh Thirlway, The Law and Procedure of the International Court of Justice: Fifty Years of Jurisprudence, vol II (OUP 2013) 1668-1669.

${ }^{11}$ Mavrommatis Palestine Concessions, Objection to the Jurisdiction of the Court, Judgment of August 30th, 1924, PCIJ, Series A, No 2 (Mavromattis).

12 Treaty of Peace with Turkey Signed at Lausanne (adopted 24 July 1923, entered into force 6 August 1924) 28 LTS 11.
} 


\section{Formalism Versus Realism: The International Court of Justice and the Critical Date for Assessing Jurisdiction}

been ratified, this circumstance would now be covered by the subsequent deposit of the necessary ratifications. ${ }^{13}$

This classic formulation of the realistic approach to assessing the critical date for jurisdiction has since passed into the annals of international law as the 'Mavromattis principle'.

The PCIJ's position that it would not permit a formalist approach to temporal matters to preclude jurisdiction was reiterated twelve months later in Certain German Interests, in which it once again opined that it would not 'allow itself to be hampered by a mere defect of form, the removal of which depends solely on the Party concerned'.${ }^{14}$ In this respect, the central pillar of the realism embodied by the Mavromattis principle is the upholding of jurisdiction in circumstances where an applicant would be entitled to file fresh proceedings with any previous procedural defects cured. Conversely, the formalist approach disregards any subsequent developments and assesses jurisdiction strictly by reference to the date of seisin.

The procedural rationale for the realism encapsulated by the PCIJ jurisprudence is axiomatic. In situations where jurisdictional defects are resolved between the date of seisin and the Court's ruling on jurisdiction, an adverse finding merely requires the applicant to go through the formalities of commencing a fresh claim. The force of the Court's judgment is therefore limited to a temporary stay that, through the delay of proceedings and increases in costs (both for the parties and for the Court itself), serves only to diminish judicial efficiency and delay settlement of the dispute. Justifiably described by Schreuer as anomalous and paradoxical, such consequences are not consistent with the promotion of the Court as a just and efficient adjudicator of international disputes. ${ }^{15}$ The realist approach is thus validated on both procedural and substantive grounds, ameliorating judicial profligacy whilst increasing the quantity of cases that come before the Court.

The contrasting formalist approach to assessing the critical date has its own merits, as the Court recognised in Croatian Genocide. ${ }^{16}$ First, the consistent assessment of jurisdiction by reference to a single and clearly identifiable date promotes legal certainty. This is particularly important in reverse situations to the Mavromattis formulation, where a jurisdictional precondition fulfilled at the date of filing is subsequently annulled or invalidated. ${ }^{17}$ Second, jurisdictional formalism is intended to prevent the premature

\footnotetext{
${ }^{13}$ Mavromattis (n 11), 34.

${ }^{14}$ Certain German Interests in Polish Upper Silesia, Jurisdiction, Judgment, No. 6, 1925, PCIJ, Series A, No 6 (Certain German Interests), 14.

${ }^{15}$ Schreuer (n 9), 10.

${ }^{16}$ Croatian Genocide (n 5), [80].

17 Thirlway (n 10) 1668.
} 
commencement of proceedings concerning disputes that may not yet be suitable for adjudication. By encouraging the timely filing of applications, formalism purports to enhance the Court's effectiveness by promoting judicial economy and encouraging alternative dispute resolution, ensuring that only disputes that are fully crystallised come before the Court for adjudication. $^{18}$

It is indisputable that these virtues of formalism are paramount within the Court's practice. However, there is a disparity between the protected norms elucidated above that compels a preference for the realism of the Mavromattis principle. The imperative of avoiding the denial of justice and procedural delay that results from the formalist position must outweigh the need to preserve any artificial strand of legal certainty, particularly when such certainty can nonetheless be attained through consistent application of the Mavromattis principle. Further, requiring applicants to go through the arbitrary steps of filing a fresh claim negates any judicial economy achieved through the avoidance of premature proceedings. The denial of jurisdiction in circumstances where an applicant would be entitled to file anew with all procedural defects resolved is not only 'excessively formalistic' but ultimately ineffective, ${ }^{19}$ and the Court should not undermine its own legitimacy through engaging in acts of futility. As Kolb observes, preference of a realistic approach should therefore be a corollary of the Court's desire 'not to excessively hinder access to it, although obviously without ignoring the peremptory rules regarding its jurisdiction' ${ }^{20}$

\section{JURISPRUDENCE OF THE COURT: FROM REALISM TO FORMALISM}

\section{Early realism}

Following the jurisprudence of the PCIJ, the Court in early decisions such as Northern Cameroons signalled that it would maintain a realistic approach to temporal matters of jurisdiction. ${ }^{21}$ The critical date demanded further evaluation in the Court's decision on preliminary objections in the landmark Nicaragua case, in which the cure of procedural defects was just one of a myriad of jurisdictional issues. ${ }^{22}$

\footnotetext{
${ }^{18}$ Shany (n 3$)$ 88-89.

${ }^{19}$ Andreas Zimmermann and others (eds), The Statute of the International Court of Justice: a Commentary (2nd edn, OUP 2012) 706.

${ }^{20}$ Robert Kolb, The Elgar Companion to the International Court of Justice (Elgar 2014) 38.

${ }^{21}$ Case concerning the Northern Cameroons (Cameroon v United Kingdom), Preliminary Objections, Judgment, ICJ Reports 1963, 15, 28.

${ }_{22}$ Military and Paramilitary Activities in and against Nicaragua (Nicaragua $v$ United States of America), Jurisdiction and Admissibility, [1984] ICJ Reports. 392 (Nicaragua).
} 


\section{Formalism Versus Realism: The International Court of Justice and the Critical Date for Assessing Jurisdiction}

The Court in Nicaragua again adopted an expansive approach to its own jurisdiction by applying a realist approach to temporal aspects of procedure. It was observed that any obstacle to jurisdiction caused by the failure to refer during pre-filing negotiations to a bilateral 1956 Treaty of Friendship, Commerce and Navigation was no longer pertinent, ${ }^{23}$ as the US had subsequently been notified of the alleged breaches of that treaty during the early stages of proceedings. ${ }^{24}$ Citing the judgment of the PCIJ in Certain German Interests, the Court stated that '[i]t would make no sense to require Nicaragua now to institute fresh proceedings based on the Treaty, which it would be fully entitled to do'. ${ }^{25}$ This restatement of the Mavromattis principle represents a clear endorsement by the Court of a realistic approach to assessing the temporal satisfaction of conventional preconditions to jurisdiction.

\section{Judicial vacillation in the FRY judgments}

The realistic approach adopted in Nicaragua was largely followed by the Court in a series of cases derived from the wars of dissolution that took place in the Former Republic of Yugoslavia (the FRY) towards the end of the $20^{\text {th }}$ century. In Bosnian Genocide, ${ }^{26}$ the question of procedural defects arose in respect of the date on which the parties became bound by the Genocide Convention (the relevant jurisdictional instrument), ${ }^{27}$ with the respondent arguing that it only became a state party in 1995 (two years after filing of the application). The Court again followed the previous jurisprudence outlined above, holding that jurisdiction should not be declined because 'Bosnia and Herzegovina might at any time file a new application, identical to the present one, which would be unassailable in this respect' ${ }^{28}$

The Court adopted the same position in the Croatian Genocide case. Despite beginning by reiterating the general position of assessing jurisdiction as of the date of filing, ${ }^{29}$ the Court found favor in its own jurisprudence by electing to follow the policy of 'realism and flexibility' espoused in Mavromattis and Nicaragua. ${ }^{30}$ In doing so, it took the opportunity to restate the Mavromattis principle in succinct terms that merit repeating in full:

\footnotetext{
${ }^{23}$ Treaty of Friendship, Commerce and Navigation between the United States of America and the Republic of Nicaragua, (adopted 21 January 1956, entered into force 24 May 1958) 367 UNTS 3.

${ }^{24}$ Nicaragua (n 22), [83].

25 ibid.

${ }^{26}$ Application of the Convention on the Prevention and Punishment of the Crime of Genocide, Preliminary Objections, Judgment, ICJ Reports 1996, 595 (Bosnian Genocide).

${ }^{27}$ Convention on the Prevention and Punishment of the Crime of Genocide (adopted 9 December 1948, entered into force 12 January 1951) 78 UNTS 277.

${ }^{28}$ Bosnian Genocide (n 26), [26].

29 'In numerous cases, the Court has reiterated the general rule which it applies in this regard, namely: "the jurisdiction of the Court must normally be assessed on the date of the filing of the act instituting proceedings"'; Croatian Genocide (n 5), [79]-[80].

${ }^{30}$ Croatian Genocide (n 5), [81].
} 
What matters is that, at the latest by the date when the Court decides on its jurisdiction, the applicant must be entitled, if it so wishes, to bring fresh proceedings in which the initially unmet condition would be fulfilled. In such a situation, it is not in the interests of the sound administration of justice to compel the applicant to begin the proceedings anew - or to initiate fresh proceedings - and it is preferable, except in special circumstances, to conclude that the condition has, from that point on, been fulfilled. ${ }^{31}$

The decision of the majority in Croatian Genocide was however subject to strong dissenting opinions, with Judges Owada and Skotnikov criticising the judgment as expanding the ambit of the Mavromattis principle beyond its genesis as a principle abrogating only an absence of consent at the date of filing (and not the right of a state to appear before the Court). ${ }^{32}$

Despite the definitive endorsements of the Mavromattis principle in Bosnian Genocide and Croatian Genocide, application of a realist approach was not uniform within the context of the FRY litigation. In particular, the judgment of the Court in Croatian Genocide has been described by Hernández as 'diametrically opposed' to its earlier decision in Legality of Use of Force.$^{33}$ In that case, the Court was faced with essentially the same jurisdictional obstacles as in Croatian Genocide but adopted the opposite formalist position, consequentially declining jurisdiction. This contradiction was noted by Judge Kreća in Croatian Genocide, who recognised that '[i]t is difficult to explain the heterogeneous decisions of the Court as regards the jus standi of the FRY/Serbia by reasonable differences in the legal reasoning'. ${ }^{34}$ The FRY series of cases is thus symptomatic of the dichotomy between formalism and realism in the Court's approach to jurisdiction, and how this may not be motivated by strictly legal factors.

\section{New formalism}

a) Georgia

Although tensions around the semi-autonomous regions of Abkhazia and South Ossetia had subsisted between Georgia and Russia for many decades ${ }^{35}$ the catalyst for judicial proceedings was the five-day armed conflict that began with Russian incursions into Georgian territory on 8 August 2008. In an application filed with the Court just days later on 12 August 2008, Georgia alleged a number of violations of the Convention on the Elimination of Racial Discrimination

\footnotetext{
${ }^{31}$ Croatian Genocide (n 5), [85].

${ }^{32}$ Croatian Genocide (n 5), Dissenting Opinion of Judge Owada, [14]; Dissenting Opinion of Judge Skotnikov, [1].

${ }^{33}$ Legality of Use of Force (Serbia and Montenegro v Belgium), Preliminary Objections, Judgment, ICJ Reports 2004, 279 (Legality of Use of Force); Gleider Hernández, The International Court of Justice and the Judicial Function (OUP 2014) 165.

${ }^{34}$ Dissenting Opinion of Judge Kreća in Croatian Genocide (n 5), [23].

${ }^{35}$ Natalia Lucak, 'Georgia v Russia Federation: A Question of the Jurisdiction of the International Court of Justice’ (2012) 27 Maryland Journal of International Law 323, 325-28.
} 


\section{Formalism Versus Realism: The International Court of Justice and the Critical Date for Assessing Jurisdiction}

(CERD), ${ }^{36}$ and sought to establish reciprocal jurisdiction pursuant to the compromissory clause at article 22 thereof. In response, Russia submitted a total of four preliminary objections to jurisdiction, the second of which argued that the procedural preconditions of article 22 had not been satisfied prior to the date of seisin. ${ }^{37}$ In response to an application for provisional measures made by Georgia, the Court initially held that it possessed the prima facie jurisdiction necessary to make an interim order. ${ }^{38}$ However, the Court's final decision on jurisdiction upheld Russia's second objection and consequently declined jurisdiction to hear the merits.

According to the Court, article 22 of CERD required inter alia the parties to have conducted negotiations that had 'failed, became futile, or reached a deadlock before Georgia submitted its claim to the Court. ${ }^{39}$ Having adopted this formalist position on the critical date for assessing jurisdiction, the Court reviewed the diplomatic exchanges that took place between the dispute arising and the date of filing (9-12 August 2008) and concluded that these preconditions had not been satisfied. The alternative realist approach - which would have accounted for the conduct of negotiations after the date of seisin - was advocated in strong terms by five judges in a Joint Dissenting Opinion, which lamented the Court's departure from the flexibility most recently espoused in Croatian Genocide. ${ }^{40}$

\section{b) Prosecute or Extradite}

Whilst the judgment in Georgia was the first outside the context of the FRY cases to signify a departure from the Court's previous realism, it was quickly followed by another case in which an ostensibly similar approach was adopted. In Belgium v Senegal, Belgium alleged that Senegal had breached its international obligations by failing to procure the extradition or prosecution of former Chad president Hissène Habré. ${ }^{41}$ In addition to claims premised on the Torture Convention, ${ }^{42}$ Belgium also sought to establish a cause of action under customary

\footnotetext{
${ }^{36}$ International Convention on the Elimination of All Forms of Racial Discrimination (adopted 21 December 1965, entered into force 4 January 1969) 660 UNTS 195 (CERD).

${ }^{37}$ Preliminary Objections of the Russian Federation in the Georgia case, 1 December 2009 (Russian PO), Chapter VI.

${ }^{38}$ Application of the International Convention on the Elimination of all Forms of Racial Discrimination (Georgia v Russian Federation), Provisional Measures, Order of 15 October 2008, ICJ 353 (Georgia PM).

${ }^{39}$ Georgia (n 4), [162] (emphasis added).

${ }^{40}$ Joint Dissenting Opinion of President Owada, Judges Simma, Abraham, Donoghue, and Judge ad hoc Gaja in Georgia (n 4).

${ }^{41}$ Questions relating to the Obligation to Prosecute or Extradite (Belgium v Senegal), Judgment, ICJ Reports 2012, 422 (Prosecute or Extradite).

${ }^{42}$ Convention Against Torture and Other Cruel, Inhuman or Degrading Treatment or Punishment (adopted 10 December 1984, entered into force 26 June 1987) 1485 UNTS 85 (Torture Convention); Belgium Memorial in Prosecute or Extradite (n 41), [3.05]-[3.29].
} 
international law, basing jurisdiction on the optional clause declarations made by each state pursuant to article $36(2)$ of the Statute. ${ }^{43}$

Having accepted jurisdiction in respect of the allegations made under the Torture Convention, ${ }^{44}$ the Court held that it did not have jurisdiction to adjudicate the claims made under customary law. Noting that Belgium had not during previous diplomatic exchanges referred to its claim under custom, the Court concluded that a dispute had not existed at the time of filing and accordingly that there was no jurisdiction. ${ }^{45}$ By failing to consider the existence of the dispute subsequent to the date of filing - which had been firmly established through the submissions made by the parties during proceedings - the Court pursued the same brand of formalism evident in Georgia, refusing jurisdiction in circumstances where the applicant would have been entitled to re-file with all previous procedural defects seemingly remedied. As noted in the Separate Opinion of Judge Abraham, application of a realistic approach would have led to an altogether different conclusion. ${ }^{46}$

\section{Concluding observations on judicial consistency}

It appears difficult to reconcile the conclusions reached in the new formalist cases with the realism extolled in previous judgments and culminating in Croatian Genocide. Whilst it is largely accepted that a doctrine of binding precedent does not apply to the Court, ${ }^{47}$ it has historically followed previous decisions where applicable pursuant to a general principle of judicial consistency. ${ }^{48}$ As stated by Judge Tanaka in the Barcelona Traction case, ' $\mathrm{t}$ ]he same kind of cases must be decided in the same way and possibly by the same reasoning'. ${ }^{49}$ The rationale for this approach is manifest: Guillaume observes that reliance on settled cases provides a minimum of certainty and foreseeability, ${ }^{50}$ whilst Lauterpacht describes precedent as 'a repository of legal experience to which it is convenient to adhere'. ${ }^{51}$ The Court has

\footnotetext{
43 ibid [3.30]-[3.44].

44 Prosecute or Extradite (n 41), [52].

45 ibid [54]-[55].

${ }^{46}$ Separate Opinion of Judge Abraham in Prosecute or Extradite (n 41), [18].

47 The PCIJ has stated that article 59 of the Statute was expressly intended to 'prevent legal principles accepted by the Court in a particular case from being binding on other states or in other disputes'; Certain German Interests (n 14), 19.

${ }^{48}$ Alina Kaczorowska-Ireland, Public International Law (5th edn, Routledge 2015) 52.

${ }^{49}$ Separate Opinion of Judge Tanaka in Barcelona Traction, Light and Power Company, Limited, Preliminary Objections, Judgment, ICJ Reports 1964, 6, 65.

${ }^{50}$ Gilbert Guillaume, 'The Use of Precedent by International Judges and Arbitrators' (2011) 2 Journal of International Dispute Settlement 5, 6.

${ }^{51}$ Hersch Lauterpacht, The Development of International Law by the International Court (Stevens and Sons 1958) 14.
} 
accordingly relied on persuasive authorities as justification for its decisions in a number of cases, with past rulings cited in $26 \%$ of judgments promulgated between 1948 and 2002. ${ }^{52}$

It has been suggested by Shahabuddeen that such invocations of previous judgments do not represent an application of precedent, but merely 'a statement of what the Court regarded as the correct legal position'. ${ }^{53}$ Although it has correctly been observed that predictability within international dispute resolution is in itself a relative matter, ${ }^{54}$ the approach of a single institution to application of the Mavromattis principle - a frequently occurring and relatively straightforward issue of procedure - demands a consistent philosophy. Indeed, Crawford has observed that matters of procedure perhaps even represent an exception to the general rule against stare decisis within the Court's jurisprudence. ${ }^{55}$ Plainly, the Georgia judgment critically undermines these assertions.

\section{GEORGIA - TURNING POINT OR JUDICIAL ANOMALY?}

The decision of the Court in Georgia thus created a schism within its own jurisprudence - all the more significant because it involved the explicit rejection of the Court's own prima facie conclusion at the provisional measures stage of the same case. But whether this decision was a judicial anomaly or deliberate turning point in the Court's approach remains to be seen. From a practical perspective, this ambiguity is clearly undesirable. This section will therefore seek to analyse the legal and political factors that influenced the Court's conclusions in Georgia, how that judgment has been extrapolated as judicial authority in subsequent cases, and the implications of these developments for the present status of the Mavromattis principle.

\section{Legal reasoning}

a) Submissions of the parties

In its written submissions on preliminary objections, Russia began by invoking the Joint Dissenting Opinion in Georgia PM to argue in favour of what Ghandi describes as 'the perfectly orthodox view that a dispute must exist prior to the seisin of the Court ${ }^{56}$ Having acknowledged that the Court had in previous cases departed from this general rule where

\footnotetext{
${ }^{52}$ Tom Ginsburg, 'Bounded Discretion in International Judicial Law-making' (2005) 45(3) Va J Int'1 L 631, 639.

${ }^{53}$ Mohamed Shahabuddeen, Precedent in the World Court (CUP 1996) 63, quoting from Case concerning the Temple of Preah Vihear (Cambodia v Thailand), Preliminary Objections, Judgment of 26 May 1961, ICJ Reports 1961, 17, 27.

${ }^{54}$ Robert Y Jennings, 'A New Look at the Place of the Adjudication in International Relations Today' (1998) 1 Collected Writings 450, 485-6.

55 James Crawford, Brownlie's Principles of Public International Law (8th edn, OUP 2012) 38.

56 Sandy Ghandi, 'The International Court of Justice and the Provisional Measures Order in the Georgia v Russian Federation Case' in James Green and Christopher Waters (eds), Conflict in the Caucasus: Implications for International Legal Order (Palgrave MacMillan 2010) 87; Russian PO (n 37), [3.23]-[3.32].
} 
prevailing circumstances would have enabled the applicant to file fresh proceedings, Russia then made three submissions as to why this exception (ie the Mavromattis principle) should not be applied in the instant case. First, Russia argued that the sound administration of justice would be undermined by application of the Mavromattis principle to a case with a long history that involved the premature commencement of proceedings. ${ }^{57}$ Second, Russia submitted that the Georgian application was an 'artificial case', motivated by attempts to turn claims premised on the use of force and international humanitarian law into racial discrimination. ${ }^{58}$ Third, it was suggested that a plain text reading of article 22 of CERD required satisfaction of jurisdictional preconditions prior to the date of filing. ${ }^{59}$

In its response to Russia's preliminary objections, Georgia elected not to directly address these arguments. ${ }^{60}$ Instead, it focused submissions on demonstrating that the jurisdictional preconditions (the existence of a dispute and the conduct of negotiations in respect thereof) had been substantially satisfied as at the date of filing. ${ }^{61}$ Similarly, arguments around the critical date were conspicuously absent from oral arguments made during the hearings on preliminary objections that took place in The Hague in September 2010. Submissions on this issue were seemingly limited to an unopposed suggestion by counsel for Russia that Georgia had accepted the premise that jurisdiction must be established as of the date of filing. ${ }^{62}$ Whilst it is questionable whether such an assertion was justified by reference to Georgia's written arguments, it further emphasises how the absence of submissions on the Mavromattis principle from Georgia may have influenced proceedings.

It is curious that Georgia opted not to expressly invoke the Mavromattis principle as a secondary line of argument. Notwithstanding the majority's subsequent conclusion to the contrary, ${ }^{63}$ preconditions requiring the existence of a dispute and the conduct of negotiations could arguably have been satisfied by the time jurisdiction came to be assessed, through both the procedural documents submitted to the Court and other diplomatic discussions that took place after proceedings were instituted. ${ }^{64}$ An unfavourable conclusion by the Court as to the characterisation of proceedings at the date of filing could have been entirely negated through application by the Court of the Mavromattis principle. The omission of this argument is

\footnotetext{
${ }^{57}$ Russian PO (n 37), [3.33a].

58 ibid [3.33b].

59 ibid [3.33c].

${ }^{60}$ Written Statement of Georgia on Preliminary Objections in Georgia (n 4), 1 April 2010.

61 ibid, Section II of Chapter II, 29; Section V of Chapter III, 123.

${ }^{62}$ Verbatim Record of 13 September 2010 in Georgia (n 4), submissions of Samuel Wordsworth, [2]-[3], 28.

${ }^{63}$ Georgia (n 4), [180]-[184].

${ }^{64}$ As was the case in Nicaragua (n 22), [83].
} 


\section{Formalism Versus Realism: The International Court of Justice and the Critical Date for Assessing Jurisdiction}

particularly notable given that Georgia instructed two advocates - Professors James Crawford and Philippe Sands QC - who had successfully argued in favour of application of the Mavromattis principle on behalf of Croatia in Croatian Genocide. ${ }^{65}$ In the absence of any further background on the Georgian submissions, commentators can only speculate as to the reasons for this failure to invoke the Mavromattis principle. As discussed in Section D, subsection 2 below, this decision may be indicative of a desire for jurisdiction to be refused, the result of wider political considerations that shaped Georgian litigation strategy in the case. Alternatively, it was perhaps a strategic decision intended to focus judicial minds on the prevailing circumstances at the date of seisin.

\section{b) Judgment on preliminary objections}

Perhaps reflecting the sparse attention afforded to the issue in the parties' submissions, the majority's judgment in Georgia gave short shrift to temporal matters. The Court simply reiterated at several points of the judgment that preconditions to jurisdiction must 'in principle exist at the time the Application is submitted' ${ }^{66}$ Nevertheless, the Court has been criticised for the strength of its arguments on this issue, with Quintana questioning both the inclusion of the debilitating words 'in principle' and the reference to the views of the parties on an issue that was purportedly an established principle of procedure. ${ }^{67}$ The majority's brief espousal of a formalistic approach to determining jurisdiction was also subjected to strong criticism in a Joint Dissenting Opinion promulgated by five members of the Court, who argued that the Court should have upheld jurisdiction to hear the merits of Georgia's claim. ${ }^{68}$

The joint dissenters began by acknowledging the general principle that jurisdiction must be assessed as of the date of filing. ${ }^{69}$ They then correctly observed that the Court had 'progressively relaxed' this principle, culminating in the application of the Mavromattis principle in the most recent case of Croatian Genocide. ${ }^{70}$ According to the joint dissenters, in cases such as Georgia it would be "pointlessly formalistic to refuse to take account of the fulfillment of the initially unmet condition after the filing of the application'. ${ }^{71}$ Having reaffirmed the brand of realism that had been formulated in Croatian Genocide, the joint

\footnotetext{
${ }^{65}$ See for example Croatian Genocide (n 5), Verbatim Record 29 May 2006, testimony of Professor James Crawford, [8]-[21].

${ }^{66}$ Georgia (n 4), [30]; see also [141] as regards the fulfillment of procedural preconditions under article 22 of CERD, which the Court stated must be fulfilled 'before the seisin of the Court.'

${ }^{67}$ Juan José Quintana, 'Procedural Developments at the International Court of Justice' (2011) 10 The Law and Practice of International Courts and Tribunals 507, 540.

${ }^{68}$ Joint Dissenting Opinion (n 40).

${ }^{69}$ ibid [35].

70 ibid.

71 ibid.
} 
dissent subsequently observed that "[n]one of this is reflected in the present Judgment. ${ }^{, 72}$ It was noted that the consequence of the formalistic approach adopted by the majority was that the Court was limited in its review of pre-action negotiations to a three-day period from 9-12 August 2008. There was, according to the joint dissenters, no reason for such a 'surprisingly narrow approach', particularly where the Court had 'departed from its own most recent jurisprudence, without offering the slightest justification for doing so' ${ }^{73}$

\section{c) Reconciliation with existing jurisprudence}

On initial review, the judgment of the majority in Georgia is irreconcilable with the Court's historically realistic approach and surprising in appearing to 'run contrary to the Court's move away from formalism in recent times' ${ }^{74}$ In order to integrate this decision into the historic line of consistent jurisprudence, however, attempts can nonetheless be made to reconcile the Georgia judgment with those that preceded it. In particular, the Court in Croatian Genocide made efforts to distinguish its application of the Mavromattis principle in that case from its previous refusal to do so in Legality of Use of Force. In doing so, the Court laid down two primary considerations for application of the Mavromattis principle that may have influenced the majority in Georgia.

First, the Court in Croatian Genocide reiterated that the theoretical foundations of the realist approach were built upon 'judicial economy, an element of the requirements of the sound administration of justice', and necessary to prevent the 'needless proliferation of proceedings'. ${ }^{75}$ In this respect, emphasis is placed on the intention of the applicant to file further proceedings in the event of a finding of no jurisdiction. The Court in Croatian Genocide thus distinguished its previous judgment in Legality of Use of Force on the basis that Serbia and Montenegro had made it clear that it had no intention to file fresh proceedings, and accordingly that the conceptual foundations for application of the Mavromattis principle in that case had fallen away. ${ }^{76}$ It is submitted that this approach represents an overly teleological position, requiring the Court to perform unhelpful and hypothetical assessments of future conduct and placing too much reliance on the contemporaneous intentions of the parties. Nevertheless, the failure of Georgia to reissue new proceedings since the Court's judgment on

\footnotetext{
72 ibid.

73 ibid [37].

${ }^{74}$ Kate Parlett, 'The International Court of Justice's Decision on Preliminary Objections in Georgia v Russia: Towards Formalism?' (2012) 71 The Cambridge Law Journal 56, 58.

${ }^{75}$ Croatian Genocide (n 5), [89].

76 ibid.
} 


\section{Formalism Versus Realism: The International Court of Justice and the Critical Date for Assessing Jurisdiction}

preliminary objections suggests that the Court may have taken this into consideration when declining jurisdiction.

Second, the Court noted that whereas the applicant in Croatian Genocide had explicitly requested that the Court apply the Mavromattis principle, no such request had been made in Legality of Use of Force. ${ }^{77}$ As observed in the subsection 'Judgment on preliminary objections' above, Georgia elected not to make any submissions asking the Court to adopt this position. On the basis of the guidance offered in Croatian Genocide, such failure may have justified the formalist approach that the Court adopted in Georgia. Again, however, the propriety of this consideration can be questioned. As demonstrated by the attention afforded to the same issue in the Joint Dissenting Opinion, the Court's application of fundamental principles of its own jurisprudence should not be dependent on the submissions of the parties. Notably, the Court has proven itself willing to assess similar jurisdictional issues ex officio in subsequent cases. ${ }^{78}$

\section{Policy considerations}

\section{a) Independence of the Court}

The Court represents the principal judicial organ of the United Nations (UN). ${ }^{79}$ Despite this clear delineation of powers, concerns around its independence nonetheless abound, particularly as regards its relationship with the UN Security Council (UNSC). Mackenzie and Sands argue that the unwritten custom permitting each of the five permanent members of the UNSC to have a judge on the bench at all times raises questions about judicial independence ${ }^{80}$ Further, the UNSC exercises a primary role in the enforcement of the Court's judgments, with article 94(2) of the UN Charter giving the UNSC powers '[to] make recommendations, or decide upon measures to be taken to give effect to the judgment'. Ogbodo has consequently argued that it is "prima facie untidy for the same "big five" to wield enormous powers both in the Security Council and the ICJ [International Court of Justice]' ${ }^{81}$ This assertion is borne out by the events that followed the refusal of the United States to comply with the Court's judgment in Nicaragua, when that state was able to exercise its own right of veto in the UNSC to prevent enforcement action being taken against itself. ${ }^{82}$

\footnotetext{
77 ibid.

${ }^{78}$ Separate Opinion of Judge Abraham in Prosecute or Extradite (n 41), [19]-[20].

79 Article 1 of the Statute.

${ }^{80}$ Ruth Mackenzie and Philippe Sands, 'International Courts and Tribunals and the Independence of the International Judge' (2003) 44 Harvard International Law Journal 271, 278.

${ }^{81} \mathrm{~S}$ Gozie Ogbodo, 'An Overview Of The Challenges Facing The International Court Of Justice In The 21st Century’ (2012) 18 Annual Survey of International \& Comparative Law 93, 107.

${ }^{82}$ Docs. S/18250 (1986) and S/PV 2704 (1986).
} 
The level of control exercised by the UNSC over the Court's practice is unquestionably unwise. By establishing a permanent presence for the UNSC within the composition of the Court, and by making the UNSC the chief enforcer of the Court's judgments, the judicial arm of the UN leaves itself exposed to the political interests of a group of states that already exerts disproportionate levels of power within the wider organisation. Even if the independence of the Court is able to withstand this level of exposure, the mere impression of any absence of impartiality is sufficient to undermine its legitimacy. Although Coleman argues that the Court has in certain cases taken positive and successful steps to distance itself from political considerations, ${ }^{83}$ it has in others been criticised for according undue weight to outside influences. Wilson has described the judgment of the Court in Armed Activities on the Territory of the Congo ${ }^{84}$ as betraying a judicial institution that had 'derogated from its own duties, and revealed the high degree to which this formally independent legal body can be influenced by grave political considerations'. ${ }^{85}$ Similar views were forcefully expressed in the Separate Opinion of Judge Simma in the same case, who criticised the Court's apparent deference to previous determinations made by the UNSC. ${ }^{86}$

Historically, the Court has not been reluctant to acknowledge the inherently political nature of the disputes that it adjudicates. As was stated in Tehran Hostages, 'legal disputes between sovereign States by their very nature are likely to occur in political contexts, and often form only one element in a wider and longstanding political dispute between the States concerned' ${ }^{87}$ Nonetheless, it has consistently held that the presence of fundamentally political aspects of cases does not preclude the Court's ability to adjudicate. ${ }^{88}$ This approach has been criticised by commentators such as Sugihara, who suggest that the legitimacy of the Court would be consolidated through 'resolving routine and politically less important disputes rather than dealing with politically sensitive cases'. ${ }^{89}$ Such reservations are however misplaced. Although the Court must not abandon its primary role as a fundamentally legal institution, an

\footnotetext{
${ }^{83}$ Examples include Nicaragua and the Lockerbie Case (Provisional Measures), ICJ Reports 1992, 3; Andrew Coleman, 'The International Court of Justice and Highly Political Matters' (2004) 4 Melbourne Journal of International Law 29.

${ }^{84}$ Armed Activities on the Territory of the Congo, Democratic Republic of the Congo v Uganda, Judgment, Merits, ICJ Reports 2005, 168 (Armed Activities).

85 Page Wilson, Aggression, Crime and International Security: Moral, Political and Legal Dimensions of International Relations (Routledge 2009) 106.

${ }^{86}$ Separate Opinion of Judge Simma in Armed Activities (n 84), [3]; See also the Separate Opinion of Judge Elaraby in Armed Activities (n 84), [11].

${ }^{87}$ United States Diplomatic and Consular Staff in Tehran, Judgment, ICJ Reports 1980, 3, [37].

${ }^{88}$ Coleman (n 83), 42.

${ }^{89}$ Takane Sugihara, 'The Judicial Function of the International Court of Justice' in A Sam Muller, David Raič and JM Thuránszky (eds), The International Court of Justice: Its Future Role after Fifty Years (Martinus Nijhoff 1997) 138.
} 


\section{Formalism Versus Realism: The International Court of Justice and the Critical Date for Assessing Jurisdiction}

approach that requires it to shy away from making decisions of political consequence would render it superfluous within the modern geopolitical landscape. A functionally apolitical world court would not be compatible with the modern demands of international dispute resolution. Nonetheless, the historic truism that 'hard cases make bad law' may equate at the international level to the Court's adjudication of highly political cases. ${ }^{90}$

\section{b) Formalism as political expediency}

For present purposes, concerns around the impact of political considerations are particularly apposite within the context of the Georgia case. Comparisons in this respect may also be drawn with the judgment of the Court in Legality of Use of Force. In both cases, the non-application of the Mavromattis principle arguably led to the discontinuance of cases in a manner that was politically expedient for both the disputing parties and the Court itself.

First, it has been suggested that the formalism adopted by the Court in these cases represented an escape route for the respective applicants. Okowa submits that the application in Georgia was nothing more than a 'convenient platform for the public articulation of a political grievance... without any intention of engaging the judicial function in the actual settlement of the dispute'. ${ }^{91}$ The implication, Palchetti argues, is that Georgia's claim was therefore only part of a wider political strategy whereby ' $[r]$ esort to the Court may serve the purpose of bringing a case before world public opinion' ${ }^{92}$ Such views are reinforced by the political rhetoric that emanated from Georgia in response to the upholding of Russia's preliminary objections, where public officials welcomed the judgment as 'beneficial for Georgia' and characterised it as nothing more than a temporary suspension of proceedings. ${ }^{93}$ It remains significant that Georgia has not to date filed fresh proceedings against Russia. As regards Legality of Use of Force, Kolb notes that the initial filing of the claims by Serbia in 1999 had been the result of a concerted effort by the Milošević government to create difficulties for NATO states; by 2004, Serbia was seeking political conciliation with the respondents, and the objectives behind the initial applications had therefore fallen away. ${ }^{94}$ By invoking a formalistic procedural bar to jurisdiction, the Court absolved the applicants in these cases from

\footnotetext{
${ }^{90}$ Sugihara (n 8989) 138, as cited in Coleman (n 83), 43.

${ }^{91}$ Phoebe Okowa, 'The International Court of Justice and the Georgia/Russia Dispute' (2011) 11 Human Rights Law Review 739, 755.

92 Paolo Palchetti, 'The Activity of the International Court of Justice in 2008' (2008) 18 The Italian Yearbook of International Law 201, 211-212.

${ }^{93}$ Kevin Jon Heller, 'Guest-Post: Anna Dolidze on the ICJ Judgment in Georgia v Russia' (Opinio Juris, 7 April 2011) <http://opiniojuris.org/2011/04/07/guest-post-anna-dolidze-on-the-icj-judgment-in-georgia-v-russia/> accessed 22 August 2015.

${ }^{94}$ Robert Kolb, The International Court of Justice (Bloomsbury Publishing 2013) 1179-1180.
} 
having to make humbling political climb-downs by discontinuing claims that they no longer wished to pursue.

Second, both cases alleged significant breaches of international law committed by permanent members of the UNSC. A judgment on the merits in the Georgia case would have required the Court to rule on alleged breaches of CERD by Russia, whilst the application filed by Serbia in Legality of Use of Force asked the Court to adjudicate on an allegedly unlawful use of force by members of NATO (including the United States, United Kingdom and France). Given the subject matters and respondents involved, these cases represent the epitome of politically sensitive disputes that might come before the Court. Suspicions of judicial avoidance on political grounds are inevitable given the permeation of the UNSC's influence within the Court's framework, with Blum suggesting that the Court in Legality of Use of Force took refuge in a formalist approach as a 'convenient escape route'. ${ }^{95} \mathrm{He}$ contrasts this position with the decision to apply the Mavromattis principle in Bosnian Genocide, suggesting that the enormity of the crimes committed in Bosnia rendered it impossible from a policy perspective for the Court to refuse jurisdiction on the basis of 'purely technical grounds' ${ }^{96}$ If the Court was reluctant to adjudicate on this basis in Legality of Use of Force, then it is not difficult to sustain contentions that similar concerns may have led to the Court declining jurisdiction in Georgia, the first dispute involving Russia in the Court's history. ${ }^{97}$ Such conclusions carry particular weight absent the normative force of crimes on the scale of those alleged in Bosnian Genocide and Croatian Genocide. As Shany suggests, the value of the Georgia judgment is perhaps then limited to the extent to which it is 'illustrative of judicial avoidance techniques, as well as apprehension of alienating important players or major segments of the international community' ${ }^{98}$

\section{c) Politics on the bench}

Some supplementary thoughts can also be posited on the influence of political machinations within the Court itself. Posner and de Figueiredo observe that judges vote for their home state in around $90 \%$ of cases, and otherwise for those states most similar to their own in terms of wealth, culture and politics. ${ }^{99}$ Such hypotheses are seemingly borne out by the decision in

\footnotetext{
${ }^{95}$ Yehuda Blum, 'Was Yugoslavia a member of the United Nations in the years 1992-2000?' (2007) 101 AJIL $800,815$.

96 ibid.

${ }^{97}$ Phoebe Okowa, 'The Georgia v Russia Case: A Commentary' (Hague Justice Portal, 26 January 2009) $<$ http://www.haguejusticeportal.net/index.php?id=10221> accessed 22 August 2015.

98 Shany (n 3) 176.

${ }^{99}$ Eric A Posner and Miguel de Figueiredo, 'Is the International Court of Justice Biased?' (2005) 34 The Journal of Legal Studies 599, 624.
} 


\section{Formalism Versus Realism: The International Court of Justice and the Critical Date for Assessing Jurisdiction}

Georgia. In addition to Judge Skotnikov of Russia voting to uphold the preliminary objections of his nominating state, the votes of the respective Chinese judges in both Georgia PM (Judge Shi) and Georgia (Judge Xue) went in favour of Russia, a traditional geopolitical ally. Given China's own tumultuous political relationship with regions of varying degrees of autonomy, the subject matter of the dispute in Georgia and the factual matrix giving rise to it would also have undoubtedly been cause for concern in Beijing. In contrast, judges from France (Judge Abraham) and the United States (Judge Donoghue) - other permanent members of the UNSC with whom Russia has historically experienced less cordial relations - voted to apply the Mavromattis principle and uphold jurisdiction.

At a micro level, the change in position that occurred between 2008 and 2011 ostensibly turned on a three-vote swing on the bench. In addition to an apparent volte-face by Judges Keith and Sepúlveda Amor, the replacement of Rosalyn Higgins with Christopher Greenwood as judge for the United Kingdom also facilitated a decisive change in the voting. Higgins, an indefatigable human rights advocate who previously served for a decade on the UN Human Rights Committee, voted to uphold jurisdiction in Georgia PM and would unquestionably have seized the opportunity to further the development of international human rights law in Georgia. Greenwood's election to the Court during the intervening years and subsequent vote in favour of the majority decision against jurisdiction was therefore another institutional component in the final outcome.

\section{Georgia as authority: Prosecute or Extradite}

The first indication that Georgia was perhaps representative of a burgeoning trend of formalism would come just a year later in Prosecute or Extradite. As in Georgia, legal reasoning on the majority's non-application of the Mavromattis principle was meagre. More detailed scrutiny was therefore left to the Separate Opinion of Judge Abraham, who dissented on the Court's finding of no jurisdiction (as he had as a signatory to the Joint Dissenting Opinion in Georgia).

For Judge Abraham, the Court in Prosecute or Extradite had not followed the position adopted in Georgia but gone a 'particularly clear step further in the formalistic approach'. ${ }^{100}$ The result of this was that the applicability of the Mavromattis principle as endorsed in Croatian Genocide was now in question. ${ }^{101}$ This conclusion was largely premised on Abraham's argument that the Georgia judgment did not constitute a 'departure from the former jurisprudence of the Court', ${ }^{102}$ seemingly because the Court's non-application of the

\footnotetext{
${ }^{100}$ Separate Opinion of Judge Abraham in Prosecute or Extradite (n 41), [18].

101 ibid.

102 ibid [16].
} 
Mavromattis principle in that case was ultimately immaterial to the conclusions reached and therefore represented obiter dicta. ${ }^{103}$ Moreover, Abraham noted, the majority in Georgia had 'very prudently' stated that the general rule that the dispute must exist as at the date of filing applied only 'in principle'. ${ }^{104}$

Abraham's attempts to distinguish Georgia from previous cases are not persuasive. Even once the majority in Georgia had concluded that the precondition of negotiation had not been settled at any time prior to the Court's judgment on preliminary objections, a realist approach could still have been maintained through a parallel analysis that reiterated the applicability of the Mavromattis principle whilst simultaneously acknowledging that it did not in Georgia alter the outcome. In contrast, the Court simply restated the general rule that jurisdiction be assessed at the date of seisin. Abraham's suggestion that Georgia did not in this respect represent a departure from cases such as Croatian Genocide therefore has an air of the artificial. Nevertheless, Prosecute or Extradite represents a definite furtherance of the formalist trend first identifiable in Georgia for the following reason identified by Abraham:

$[T]$ his is the first time in the Court's entire jurisprudence that it has declined to hear one part of a case on the basis of the lack of a dispute between the Parties, even though the dispute clearly exists on the date of the Court's Judgment and was apparent in the proceedings before the Court. ${ }^{105}$

On this basis, Abraham's stated concern for the future of the realistic approach most recently elucidated in Croatian Genocide is well-founded.

The non-application of the Mavromattis principle in Prosecute or Extradite has however been subject to the same accusations of judicial avoidance that have plagued other formalist decisions. Kreß criticises the Court's refusal to extend its analysis to include customary law principles as 'the most recent instance of the Court's inclination to avoid certain difficult issues pertaining to the law of armed conflicts'. ${ }^{106}$ This was further reflected in the Dissenting Opinion of Judge ad hoc Sur, who characterised the Court's application of the formalist approach as an unjustified and unfounded means of evading the deliberation and potential denial of the customary rule claimed by Belgium. ${ }^{107}$ Sur concluded on stronger terms

\footnotetext{
103 ibid [16]-[17].

104 ibid [16].

105 ibid [18].

${ }^{106}$ Claus Kreß, 'The International Court of Justice and the Law of Armed Conflicts' in Christian J Tams and James Sloan (eds), The Development of International Law by the International Court of Justice (OUP 2013) 290. ${ }^{107}$ Dissenting Opinion of Judge ad hoc Sur in Prosecute or Extradite (n 41) [18].
} 
by accusing the Court of having 'failed fully to carry out its task of settling the dispute'. ${ }^{108}$ On this basis, the normative reliance on formalism in Prosecute or Extradite is perhaps no more authoritative than the politically charged conclusions in Georgia and Legality of Use of Force.

\section{Concluding observations on the current applicability of the Mavromattis principle}

It is perhaps too early to offer a full evaluation of whether Georgia represents a turning point in the Court's approach to the Mavromattis principle. Despite the initial support offered by the decision in Prosecute or Extradite, reliance on two judgments is sufficient only to discern an emerging trend rather than a decisive departure from almost a century of contrasting jurisprudence. Until the Court returns to this issue in future cases, observations as to the true impact of Georgia will therefore remain conjecture. Nevertheless, inferences can be drawn from the relevant jurisprudence with a view to approximating the Court's current position on the Mavromattis principle. On this basis, it is submitted that the new formalist cases are not indicative of a pivotal shift in legal reasoning within the Court. Instead, they demonstrate that application of the Mavromattis principle represents a discretionary jurisdictional filter that facilitates the advancement of cases that the Court wishes to hear and impedes those it does not. The Court therefore adopts a teleological, ad-hoc approach to each case that elides any consistent jurisprudential philosophy. Several observations can be made in support of this conclusion.

First, the absence of detailed legal reasoning to justify non-application of the Mavromattis principle in the new formalist cases undermines any normative reliance on those decisions as authority for a decisive change in approach. In such circumstances, the influence of external realpolitik must be attributed greater normative weight. Second, the refusal by the Court to commit to a comprehensively reasoned and definitive position in favour of formalism (to be contrasted with the willingness of the dissenters in Georgia and Prosecute or Extradite to come out firmly in support of realism) can be seen as the Court keeping its options open, preserving for itself the ability to fluctuate between the different positions where convenient in future cases. Third, whilst it has been argued that the cases in which a formalist approach has been applied can be largely attributed to external political considerations or judicial avoidance rather than strict evolution in jurisdictional ratio decidendi, the same can also arguably be said of the preceding realist cases.

As noted by Shany, the decisions to apply the Mavromattis principle in Nicaragua and Croatian Genocide were perhaps equally motivated by institutional policy considerations, and

108 ibid. 
in particular by the 'desire of the Court to adjudicate use of force cases, as part of its mandate of contributing to the maintenance of international peace and security'. ${ }^{109}$ On this basis, the Mavromattis principle has only ever been a convenient means of case selection, with any artificial strand of historic consistency indicative only of the Court's epochal willingness to adjudicate politically sensitive cases. This oscillating approach has continued to the present day, where the ad-hoc adoption of the formalist approach in recent cases remains demonstrative only of the Court's willingness to disregard its broader institutional goals and engage in a form of case-selection predicated on judicial and political convenience.

\section{E. EFFECTIVENESS OF THE COURT}

This paper has outlined some of the procedural difficulties that result from the Court's vacillating methodology for ascertaining the critical date for jurisdiction. Yet beyond the narrower sphere of preliminary objections, the application of a formalist approach to jurisdiction (whether on a blanket or ad-hoc basis) has a number of wider implications that resonate throughout the Court's entire institutional function. To properly assess the full consequences, this paper will first consider the Court's broader objectives as the world's premier judicial institution, a topic that has itself been the subject of much debate. Having expressed a view on this issue, it will then consider the implications of recent jurisprudence on the Court's overall effectiveness, before finally seeking to plot a more coherent path forward.

\section{The Court's essential function}

Debate around the proper scope of the Court's role within the international legal order has endured since its establishment. Academic theory has generally focused on two polarised theories, broadly categorised by Kolb as judicial activism and judicial restraint. ${ }^{110}$ The former advocates an expansive and confident Court, tackling a high volume of wide-ranging cases and using its docket as a means of facilitating the development of international law; the latter ascribes the Court a narrower, more conservative function, deferring strictly to the intentions of states and adjudicating only those issues in dispute. This philosophical divergence echoes the dichotomy between realism and formalism evident within the Court's approach to jurisdiction. Any normative analysis of how the Court should exercise its mandate at the jurisdictional level thus necessitates a prior conclusion on its broader function as an international judicial institution.

\footnotetext{
${ }^{109}$ Shany (n 3) 91.

${ }^{110}$ Kolb (n 94) 1174-1175.
} 


\section{Formalism Versus Realism: The International Court of Justice and the Critical Date for Assessing Jurisdiction}

The Court itself has in the past endorsed the narrower interpretation of its own mandate, explicitly rejecting any notion that it possesses either the power or inclination to explicitly develop the law. This was acknowledged in its advisory opinion in Nuclear Weapons, where the Court opined that 'its task is to engage in its normal judicial function of ascertaining the existence or otherwise of legal principles and rules'. ${ }^{111}$ This conservative view places emphasis on judicial restraint and a cautious approach to adjudicating claims that limits the Court's function to the strict settlement of individual disputes. Proponents of this view find conventional support in article 59 of the Statute, which Zimmermann and others suggest was 'intended to underline the opinion that the Court should not be considered a law-making or law-creating institution'. ${ }^{112}$ There is also an institutional imperative for this approach, with traditionally conservative states likely to withdraw consensual jurisdiction in response to any suspicion that the Court is overreaching its constitutional directive. ${ }^{113}$ Berman therefore submits that the Court has to date adopted an 'essentially conservative' approach to deciding contentious cases, emphasising fair and objectively reasoned settlements to specific disputes as opposed to using cases as a means of making pronouncements that purport to develop the law. ${ }^{114}$

In contrast, supporters of judicial activism view the Court's role as facilitating the development and innovation of international law. For commentators such as de Visscher, this is the 'essential function' of the Court. ${ }^{115}$ This view ascribes to the Court a quasi-legislative role that enables it to make what Lauterpacht calls a 'tangible contribution to the development and clarification of the rules and principles of international law'. ${ }^{116}$ Although the Court has been characterised as a mere 'agent' influencing the process of legal development, ${ }^{117}$ this view devalues the significant contributions made to the law around subject matters such as maritime delimitation ${ }^{118}$ and state responsibility ${ }^{119}$. Accordingly, assertions from commentators such as Berman that the Court does not engage in law-making are unconvincing. Higgins, for instance,

\footnotetext{
${ }^{111}$ Legality of the Threat or Use of Nuclear Weapons, Advisory Opinion, ICJ Reports 1996, 226, [18].

112 Andreas Zimmermann and others (eds), The Statute of the International Court of Justice: a Commentary (OUP 2006) 1233.

${ }^{113}$ Kolb (n 9494) 1175.

${ }^{114}$ Franklin Berman, 'The International Court of Justice as an 'Agent' of Legal Development?' in Tams and Sloan (n 106) 11-12.

115 Charles de Visscher, Theory and Reality in Public International Law (Princeton University Press 1968) 390.

116 Lauterpacht (n 51) 5.

${ }^{117}$ Christian J Tams and Antonios Tzanakapolous, 'Barcelona Traction at 40: The ICJ as an Agent of Legal Development' (2013) 23 Leiden Journal of International Law 781.

118 Yoshifumi Tanaka, Predictability and Flexibility in the Law of Maritime Delimitation (Bloomsbury 2006) 325.

${ }^{119}$ See James Crawford, 'The International Court of Justice and the Law of State Responsibility' in Tams and Sloan (n 106) 86.
} 
suggests that discharge of the judicial function in even the narrowest sense will inevitably result in development of the law. ${ }^{120}$ The more accurate view is therefore Hernández's contention that the Court fulfils an enhanced role as 'a powerful and active actor in the creation of the law.' 121

In practice, an expansive approach by the Court to development of the law is to be welcomed. In a system as decentralised and fragmented as international law - absent a singular legislature able to express a normative consensus among states, and subject to nebulous constructs such as state practice and opinio juris - the Court should embrace its ability to contribute to a more coherent body of law. In such circumstances, it is legitimate and convenient that 'vacuums and failures observed in the rules in force are either filled up or corrected by the international judiciary'. ${ }^{122}$ Failure by the Court to seize any reasonable opportunity to pronounce on important legal matters exacerbates not only the inherent ambiguities of international law, but also its own irrelevance as a judicial institution. Its approach to assessing jurisdiction must therefore be commensurate with this primary objective. Hence, by expanding the circumstances in which a Court can uphold jurisdiction to pronounce upon the applicable law relevant to the merits of a claim, the approach most consistent with a more effective Court is the brand of realism exemplified by application of the Mavromattis principle.

\section{Implications of the Court's current approach}

a) Inhibition of development of the law

It has been argued above that the primary function of the Court should be the development of international law. Boyle and Chinkin observe that the ability of the Court to fulfil this role ultimately depends on 'how many cases are brought... and the significance of those cases in terms of raising new and contested legal issues'. ${ }^{123}$ Whilst this view is superficially correct, it overlooks an important intervening factor that also impacts the Court's ability to develop the law: the Court's own approach in cases that turn on an exercise of jurisdictional discretion. By necessitating the refusal of jurisdiction in a greater number of cases and thereby reducing the range of substantive law matters it is able to adjudicate on, the formalist approach to assessing the critical date has a detrimental impact on the Court's broader institutional effectiveness.

The implications of jurisdictional formalism for the evolution of international law are evident from the case law. The Court's non-application of the Mavromattis principle in

\footnotetext{
${ }^{120}$ Rosalyn Higgins, Problems and Process: International Law and How We Use It (OUP 1993) 202.

${ }^{121}$ Hernández (n 33) 92-93.

122 Juan José Quintana, 'The International Court of Justice and the Formulation of General International Law: The Law of Maritime Delimitation as an Example’ in Muller, Raič and Thuránszky (n 89) 371.

${ }^{123}$ Alan Boyle and Christine Chinkin, The Making of International Law (OUP 2007) 269.
} 


\section{Formalism Versus Realism: The International Court of Justice and the Critical Date for Assessing Jurisdiction}

Georgia deprived the international community of clarity on two emerging and integral aspects of international human rights law: the extraterritorial application of CERD and its interaction with international humanitarian law during times of armed conflict. ${ }^{124}$ Similarly in Prosecute or Extradite, a formalist approach to the critical date perpetuated a lacuna in customary international law that the Court apparently did not wish to clarify. In contrast, the application of a realistic approach in Croatian Genocide facilitated the promulgation by the Court of a judgment that made significant contributions to the law around the crime of genocide. ${ }^{125}$

Application of the formalist approach thus represents a clear derogation of the Court's primary function as a principal contributor to the development of international law. Further, recent cases offer support for d'Aspremont's proposition that 'the time of an active Court purposely embarking in the development of international law through obiter dicta is bygone'. ${ }^{26}$ The consequences of this position have been summarised by Forcese, who criticises the Georgia judgment as 'a further refinement of the ICJ's inimitable ability to limit its own relevance'. ${ }^{127}$ In light of the conclusions reached above, it is unfortunately difficult to offer much opposition to this view.

\section{b) Formalism and realism as ad-hoc means of case selection}

The Court's exercise of jurisdictional discretion on an ad-hoc basis has two primary implications for the Court's effectiveness. First, the Court's wavering approach to application of the Mavromattis principle threatens judicial consistency, an integral pillar of jurisprudence supported by values such as 'legitimacy, credibility, effectiveness, and the perceived fairness of international law.' ${ }^{128}$ This was noted by Judge Abraham in Prosecute or Extradite, who observed that 'the series of recent Judgments does not convey a great impression of consistency'. ${ }^{129}$ Shany has correctly identified the flaws inherent in the ad-hoc approach, suggesting that the Court's different treatment of similar jurisdictional problems on the grounds

\footnotetext{
${ }^{124}$ Brian Itami, 'ICJ Upholds Russian Preliminary Objections in Georgia Dispute' (Harvard National Security Journal, 25 April 2011) <http://harvardnsj.org/2011/04/icj-upholds-russian-preliminary-objections-in-georgiadispute/> accessed 22 August 2015.

${ }^{125}$ Application of the Convention on the Prevention and Punishment of the Crime of Genocide (Croatia v Serbia), Merits, Judgment of 3 February 2015 <http://www.icj-cij.org/docket/files/118/18422.pdf> accessed 22 August 2015.

${ }^{126}$ Jean d'Aspremont, 'The Creation of States before the International Court of Justice: Which (Il)Legality?' (Hague Justice Portal, September 2010) <http://www.haguejusticeportal.net/index.php?id=12090> accessed 22 August 2015, 3.

${ }^{127}$ Craig Forcese, 'The ICJ Refines the Art of Jurisdictional Formalism: Georgia v Russia' (International Law, 13 April 2011) <http://craigforcese.squarespace.com/public-international-law-blog/2011/4/13/the-icj-refines-theart-of-jurisdictional-formalism-georgia.html> accessed 22 August 2015.

${ }^{128}$ Yuval Shany, The Competing Jurisdictions of International Courts and Tribunals (OUP 2003) 117.

${ }^{129}$ Separate Opinion of Judge Abraham in Prosecute or Extradite (n 411) [18].
} 
of political convenience undermines the credibility of its entire jurisdictional matrix. ${ }^{130}$ If credence is given to Higgins's suggestion that coherence and consistency remain the 'cornerstone of continuing respect for its jurisprudence', then application of the Mavromattis principle on an ad-hoc basis is anathema to any perception of the Court as an effective and legitimate institution. ${ }^{131}$

Second, the Court's willingness to take refuge in a formalist approach to avoid pronouncing on the merits of a claim exposes the extent to which it remains susceptible to the vagaries of realpolitik. In cases such as Georgia, the Court has seemingly conflated its own exercise of jurisdictional discretion with its desire to avoid deciding matters of political sensitivity. The result is that it has too often adopted an insipid approach to jurisdiction when it is politically convenient to do so. Although the Court cannot function within a political vacuum, it must strive to 'construct a zone for autonomous legal decision-making, immune from political considerations'. ${ }^{132}$ In such a zone, the Court's primary objective of developing international law would take priority over the type of political consideration that arguably prevailed in Georgia.

\section{A path to realism}

It is clear that an ad-hoc approach to assessing the critical date for jurisdiction is not sustainable for any legitimacy-seeking institution. To mitigate this unacceptable ambiguity, the Court must therefore opt for a decisive and blanket adoption of a singular jurisdictional paradigm. As has been argued, the procedural merits of the realistic approach, together with the need for the Court to play a central role in the development of international law, dictate that it should explicitly discard the doctrine of formalism and instead apply the Mavromattis principle wherever feasible. Focus must then turn to the most appropriate method of achieving this objective.

The least intrusive manner of implementing this change would be through an evolution in judicial reasoning in future cases. The Mavromattis principle is itself a creature of judicial law-making; whilst it is disappointing that the Court has more recently seen fit to depart from this rule, there is nothing to prevent it from returning to it. An early opportunity for such a change in policy may be provided by the Court's decision on jurisdiction in the pending case between Colombia and Nicaragua, with Colombia having submitted preliminary objections

\footnotetext{
${ }^{130}$ Shany (n 3) 82-83.

${ }^{131}$ Higgins (n 120) 202.

132 Tom Ginsburg, 'Political Constraints on International Courts' in Cesare PR Romano, Karen J Alter and Yuval Shany (eds), The Oxford Handbook of International Adjudication (OUP 2014) 484.
} 


\section{Formalism Versus Realism: The International Court of Justice and the Critical Date for Assessing Jurisdiction}

expressly invoking the formalist position adopted by the Court in both Georgia and Prosecute or Extradite. ${ }^{133}$ However, a change in approach on this basis would remain susceptible to subsequent modifications in much the same way that the new formalist cases have supplanted historic realism. In this respect, a reasoned change of approach by the Court does not adequately curtail its current ad-hoc policy.

The most revolutionary change to the Court's framework would be the disposal of the consensual model in favour of compulsory jurisdiction. The UN is almost unique in providing for the non-compulsory jurisdiction of its principal judicial organ, with organisations such as the Council of Europe, the European Union, and the World Trade Organization all requiring compulsory jurisdiction as a concomitant of membership. The consequence, Higgins suggests, is that 'the Court is too often examining objections to its own jurisdiction, rather than addressing the serious substantive problems at issue'. ${ }^{134}$ If judicial restraint is a 'logical corollary' of the Court's consensual jurisdiction, ${ }^{135}$ any notion of jurisdiction based on consent necessitates the type of formalist position adopted by the Court in more recent cases. But whilst the doctrine of compulsory jurisdiction has merits beyond the scope of this article, ${ }^{136}$ it remains an alteration to the Court's constitution as drastic as it is unlikely. It is therefore a disproportionate and inconvenient solution to the present issue.

The preferred option for firmly establishing a policy of jurisdictional realism within the Court's approach to the critical date must strike an appropriate balance between the evolution and revolution of the foregoing two proposals. To this end, there is a clearly identifiable method for establishing a definitive yet proportionate modification to the Court's jurisdictional framework. The formalist rule that jurisdiction be assessed at the date of seisin is again a jurisprudence constante derived from the Court's own jurisprudence. In the absence of any existing conventional rule, the Court could take definitive steps to provide formal clarification on this temporal element of jurisdiction in the form of a Practice Direction. Indeed, similar action has been taken in the past with the express intention of increasing productivity. ${ }^{137}$ The

\footnotetext{
${ }^{133}$ Colombia PO (n 6).

${ }^{134}$ Speech by HE Judge Rosalyn Higgins, President of the International Court of Justice, to the Sixth Committee of the General Assembly, 31 October 2008 <http://www.icj-cij.org/presscom/files/1/14841.pdf> accessed 22 August 2015, 1.

135 Hernández (n 33) 50.

${ }^{136}$ Lauterpacht considered the positive incorporation of obligatory arbitration between states an essential condition of peace: Hersch Lauterpacht, The Function of Law in the International Community (Clarendon 1933) 437.

${ }^{137}$ Practice Directions of the Court, <http://www.icj-cij.org/documents/index.php?p1=4\&p2=4\&p3=0 $>$ accessed 22 August 2015; Press Release of the Court No 2004/30, 30 July 2004 <http://www.icjcij.org/presscom/index.php?p1=6\&p2=1\&pr=94\&search=\%22soulev\%E9es\%22> accessed 22 August 2015.
} 
form of any formal directive would be the subject of extensive debate, but would essentially confirm the validity of any jurisdictional precondition absent at the date of seisin but satisfied prior to the Court's final decision on competence. Whilst the enactment of a Practice Direction on these terms might attract criticism as a unilateral and unfounded exercise of control over the Court's own procedural framework, it would nevertheless represent a conclusive and welcome shift away from formalism and also provide certainty by clarifying the ambiguity that currently prevails.

\section{F. CONCLUSION}

The effectiveness of the Court is 'decisively influenced' by its jurisdictional reach. ${ }^{138}$ Its exercise of discretion as regards temporal matters of jurisdiction is thus fundamental to its overall success. Regrettably, the Court has more recently shunned an expansive approach to upholding jurisdiction. It has instead demonstrated an increased propensity to decline jurisdiction by applying a formalistic approach to assessment of the critical date. Moreover, it has seemingly done so on an ad-hoc basis as a convenient means of judicial avoidance. It has been argued in this article that this refusal to seize jurisdiction critically undermines the legitimacy and effectiveness of the Court as the world's premier judicial institution, first by depriving it of opportunities to develop international law and second in betraying its continuing susceptibility to external realpolitik. In contrast, the Mavromattis principle - the product of a welcome display of institutional dexterity by the PCIJ almost a century ago - remains an innovative concept within the Court's procedural armoury that has facilitated important contributions at the merits stages of cases such as Nicaragua and Croatian Genocide. By disenfranchising itself from this tool and the flexibility evident in its own jurisprudence, the Court has become the architect of its own diminished relevance.

But this current reticence to adopt an expansive approach to settling international disputes need not be terminal. This article has sought to demonstrate how the Court's effectiveness could be enhanced through the adoption of a blanket approach of realism when assessing the satisfaction of jurisdictional preconditions, and made some suggestions as to how this may be achieved. Whether the Court seeks to implement any of these modifications in approach remains to be seen. One institutional cause for optimism is the recent election of Ronny Abraham as President of the Court, ${ }^{139}$ a strong proponent of the Mavromattis principle

\footnotetext{
${ }^{138}$ Yuval Shany, 'Jurisdiction and Admissibility' in Romano, Alter and Shany (n 132) 779.

${ }^{139}$ Press Release of the Court No 2015/5, 6 February 2015 <http://www.icj-cij.org/presscom/files/4/18464.pdf> accessed 22 August 2015.
} 
as evidenced by the dissents in Georgia and Prosecute or Extradite. It is to be hoped that Abraham's influence during his three years of presidency facilitates a broader shift away from formalism within the Court. Similar hope is offered by the recent judicial appointment of James Crawford, ${ }^{140}$ a moderniser who has advocated jurisdictional realism in both practice and commentary. ${ }^{141}$

These institutional developments engender some promise for the immediate future of the Court. Nevertheless, implementation of the brand of realism advocated by this article will ultimately depend on the Court's willingness and ability to overcome the permeation of political considerations into matters of jurisdictional discretion. Only then will the Court be able to abandon the present ad-hoc approach to assessing the critical date. Once it does, eschewing the needless and formalistic adherence to the date of seisin as the critical date for assessing jurisdiction and instead adopting a policy of realism in accounting for the post-filing resolution of jurisdictional defects will allow the Court to better fulfil its constitutional mandate.

\footnotetext{
${ }^{140}$ Press Release of the Court No 2014/32, 7 November 2014 $<$ http://www.icj-cij.org/presscom/files/0/18390.pdf> accessed 22 August 2015.

${ }^{141}$ Testimony in Croatian Genocide (n 65); James Crawford, 'Jurisdiction and Applicable Law' (2012) 25 Leiden Journal of International Law 471, 478.
} 